\begin{tabular}{|c|l|}
\hline Title & Nest and roost characteristics of the Ruddy-breasted Crake Porzana fusca on Minami-daito Island \\
\hline Author(s) & Sawada, Junpei; Takagi, Masaoki \\
\hline Citation & $\begin{array}{l}\text { Ornithological science, 17(1), 109-112 } \\
\text { https://doi.org/10.2326/0s.17.109 }\end{array}$ \\
\hline Issue Date & 2018-01 \\
\hline Doc URL & http://hdl.handle.net/2115/76438 \\
\hline Type & article \\
\hline File Information & Ornithol Sci 17 109-112.pdf \\
\hline
\end{tabular}

Instructions for use 


\title{
Nest and roost characteristics of the Ruddy-breasted Crake Porzana fusca on Minami-daito Island
}

\author{
Junpei SAWADA ${ }^{1}$ and Masaoki TAKAGI ${ }^{2, \#}$ \\ ${ }^{1}$ Department of Biology and Geosciences, Graduate School of Science, Osaka City University, Sugimoto, Osaka \\ 558-5858, Japan \\ ${ }^{2}$ Department of Natural History Science, Graduate School of Science, Hokkaido University, Sapporo 060-0810, \\ Japan
}

\section{ORNITHOLOGICAL SCIENCE \\ (C) The Ornithological Society of Japan 2018}

\begin{abstract}
We found five Ruddy-breasted Crake Porzana fusca nests in a swamp among emergent vegetation, and one in a dry sugarcane field more than $500 \mathrm{~m}$ (radius) from any swamp or pond, on Minami-daito Island. Nests were saucer-shaped. All of the nests in the swamp fledged chicks. It is assumed that nesting in such habitat renders nests safe from ground predators such as introduced weasels and feral cats. Roosts were similar in structure to nests, but lacked lining. It is inferred from one observation that males and females roost together at night before the egg-laying period.
\end{abstract}

Key words dry field, emergent vegetation, Porzana fusca phaeopyga, saucer-shaped nest, swamp
The Ruddy-breasted Crake Porzana fusca ranges widely across lowland areas of Southeast Asia and East Asia (Taylor \& van Perlo 1998). The species is known to inhabit reedy swamps, marshes, stream banks, reed-beds, wet grasslands at lake margins, ditches, canals, and the margins of rice fields (Taylor \& van Perlo 1998; Taylor \& Kirwan 2017); however there have been very few detailed studies of its ecology.

Two subspecies, P. f. erythrothorax and P. f. phaeopyga, occur in Japan (Ornithological Society of Japan 2012). The P. f. erythrothorax population in eastern Japan has declined (Hirano et al. 1997, 2003), most likely as a consequence of the destruction of wetlands in the region (Watanabe \& Hirano 2011). P. f. phaeopyga, which is listed as Near Threatened (NT) by Okinawa Prefecture (2005) and the Ministry of the Environment (2015), is resident on the Amami Islands, the Ryukyu Islands, and the Daito Islands (Ornithological Society of Japan 2012). In Okinawa in particular it is threatened by introduced Small Indian Mongoose Herpestes auropunctatus and Japanese Weasel Mustela itatsi, both of which prey on them. Despite its status, there have been no

(Received 25 March 2017; Accepted 29 September 2017)

\# Corresponding author, E-mail: mtakagi@eis.hokudai.ac.jp ecological or population studies of subspecies $P . f$. phaeopyga.

The goal of our research was to reveal the basic ecology of P. f. phaeopyga on Minami-daito Island, and in particular to describe the characteristics of nest and roost sites.

\section{MATERIALS AND METHODS}

\section{1) Study site}

Minami-daito Island is an oceanic island in the Pacific, which is located $360 \mathrm{~km}$ off Okinawa Island in the sub-tropical region $\left(25^{\circ} 50^{\prime} \mathrm{N}, 131^{\circ} 14^{\prime} \mathrm{E}\right.$, Fig. 1a), and has an area of about $30.6 \mathrm{~km}^{2}$ (Fig. 1b). The island is ringed with hills (highest elevation $75.8 \mathrm{~m}$; approximately $1 \mathrm{~km}$ in width), which are derived from an ancient atoll. The main lowland area enclosed by the hills is occupied by a human population of 1,400 people (mostly confined to the southwest portion of the central plain), while other areas are used predominantly for growing sugarcane. Sugarcane fields cover about $18.2 \mathrm{~km}^{2}$ (Minami-daito Village 2010). Fields are protected by wind-shelter belts (averaging $62 \mathrm{~m}$ in width; maximum height 15-20 m) comprised of Livistona chinensis, Casuarina spp., and Pinus luchuensis, but together they amount only to an area of $3.9 \mathrm{~km}^{2}$. About 30 swamps of varying sizes cover 


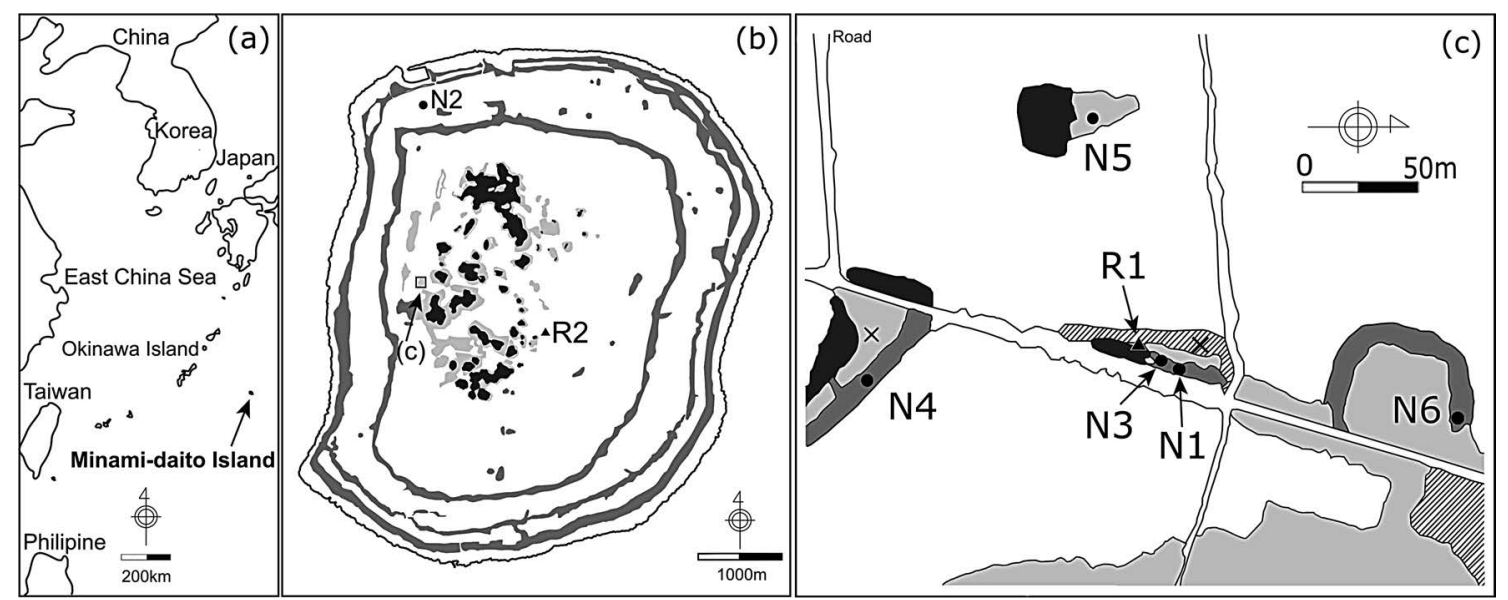

Fig. 1. (a) Location of Minami-daito Island in the Western Pacific. (b) Minami-daito Island. The dark grey portion shows water, the grey portion wind shelterbelts, the light grey portion wet forests composed of Pandanus odorifer and Bruguiera gymnorrhiza, the white portion shows mainly sugar cane fields, and (c) indicates that part of the study site shown in further detail. (c) Part of the study area in detail. The dark grey portion shows water, the grey portion the Schoenoplectus litoralis community, the light grey portion Cladium chinense and/or Typha domingensis communities, the hatched portion woodland, and the white portion sugar cane fields. Black circles indicate nests, black triangles indicate roosts, and x's indicate where crakes were captured.

a total area of approximately $2 \mathrm{~km}^{2}$. The swamps are generally surrounded by Pandanus odoratissimus and Bruguiera gymnorrhiza, and support emergent plant species such as: Typha domingensis, Schoenoplectus litoralis, Thelypteris parasitica, Persicaria tomentosa, Cladium chinense, Cyclosorus interruptus, and Panicum repens.

\section{2) General methods}

The study was conducted from March to June in 2015 and 2016. We captured and banded nine crakes in 2015 (15th April to 24th June). Crakes were marked with metal leg bands (sequentially numbered by the Japanese Ministry of the Environment), and a unique combination of coloured reflective tapes (attached to the leg bands) facilitating easy visual identification in the field. Nests were found belonging to two of the banded crakes.

In 2015, we searched in an exploratory manner for Ruddy-breasted Crake nests (see Fig. 1c). In 2016, we arbitrarily broadcasted recordings of Ruddybreasted Crake "bubbling calls" from the roadside. When crakes responded, we directed our searches for nests and roosts in the vicinity of areas from which they called (Fig. 1c). According to Taylor and van Perlo (1998) nominate $P$. f. fusca incubates its eggs for 20 days, and produces precocial chicks; therefore, when we discovered $P$. $f$. phaeopyga nests with eggs we rechecked them in order to determine clutch size, hatching date and chick status. When adult crakes were observed incubating eggs or brooding chicks, we confirmed by eye whether or not they had been banded.

\section{3) Nest and Roost Characteristics}

After nests had been used, we measured the distances between the outer edges (major and minor axes), and from bottom to rim height at the centre of the nest. Roosts consisted of roughly pushed aside macrophyte stems, and were essentially the same shape as nests, but without a lining; they often contained droppings and/or feathers. Data from roosts were collected as follows: vertical distance from outer bottom to water surface; water depth at the vertical point of the cup, and distance to the nearest dry area from roosts in swamps.

\section{RESULTS}

Two Ruddy-breasted Crake nests (N1 \& N2) were found in 2015. Four nests (N3, N4, N5 \& N6) and two roosts (R1 \& R2) were found in 2016 (Fig. 1bc). R2 was detected by chance. Nests were located in various emergent plant communities: $\mathrm{N} 1$ in Typha domingensis, N3 and N5 in Cladium chinense, and N4 and N6 in Schoenoplectus litoralis. The mean nearest distance between nests N3, N4, N5 \& N6 was $124 \mathrm{~m} \pm \mathrm{SD} 13$ (range 110-135 m; Fig. 1c). N1 
(2015) and 3 (2016) were just $5 \mathrm{~m}$ apart, and were used by the same crake (ID: 6A-25805). N1 was 12 $\mathrm{m}$ from the crake's banding site in 2015, and N3 was $19 \mathrm{~m}$ from the banding site (Fig. 1c). N4 was used by another crake (ID: 6A-25808), which had been banded $17 \mathrm{~m}$ away in 2015. N2 was not located in a swamp, but in a sugar cane field (Fig. 1b).

N1 contained five eggs on $26^{\text {th }}$ April 2015, and three hatchlings and two eggs on $2^{\text {nd }}$ May. A marked adult (ID: 6A-25805) and a chick were seen $7 \mathrm{~m}$ away from N1 on $28^{\text {th }}$ May. N2 contained six eggs on $5^{\text {th }}$ May 2016; however the clutch was abandoned by $9^{\text {th }}$ May because farm works continued around the nest; despite further checking from $9^{\text {th }}$ to $12^{\text {th }}$ May the adults were not seen again. N3 contained five eggs on $23^{\text {rd }}$ April 2016, and six eggs on $24^{\text {th }}$ April, leading us to assume that the crakes lay one egg each day during the laying-period; backdating suggests clutch initiation on $19^{\text {th }}$ April. A banded adult crake (ID: 6A-25805) incubated the clutch, while its unmarked mate was seen brooding five hatchlings and incubating one egg on $13^{\text {th }}$ May. A marked crake (ID: 6A-25808) was observed on N4 on $4^{\text {th }}$ May 2016, and we were able to verify that the same bird was brooding five chicks on the nest on $14^{\text {th }}$ May. In 2016, N5 was found on $7^{\text {th }}$ May and N6 on $14^{\text {th }}$ May, on each nest unmarked crakes were found brooding undetermined numbers of hatchlings.

Two adult crakes (ID: 6A-25805 and an unmarked individual) were found on R1 at 01:49 on $9^{\text {th }}$ April 2016. We watched an unmarked crake calling on the roost at 20:41, while the other individual was on N3 at $20: 43$ on $25^{\text {th }}$ May. We watched an adult crake on R2 at 21:55 on $18^{\text {th }}$ April, but despite inspecting the roost four more times until $26^{\text {th }}$ April (21:00 each night), we were unable to verify further use of the roost.

The Ruddy-breasted Crakes' nests were saucershaped, and typically built in a swamp (Fig. 2a). Linings consisted of pushed aside macrophyte stems such as those of Typha domingensis. N2 uniquely was built in a sugar cane field and was made from sugar cane leaves (Fig. 2b). The mean length of the major axis was $160.5 \mathrm{~mm} \pm \mathrm{SD} 23.09(\mathrm{n}=6)$ [range: $126-196 \mathrm{~mm}]$, the mean length of the minor axis was $135.7 \mathrm{~mm} \pm 22.57(\mathrm{n}=6)$ [range 104-173 $\mathrm{mm}$ ], and the mean depth of the nest lining was $24.7 \mathrm{~mm} \pm 8.04$ $(\mathrm{n}=6)$ [range 14-36 mm]. The mean vertical height from the outer bottom edge to the water surface was $41.8 \mathrm{~cm} \pm 19.56(\mathrm{n}=5)$ [range 19-66 cm]. The mean depth of water was $41.0 \mathrm{~cm} \pm 12.02(\mathrm{n}=5)$ [range $23-55 \mathrm{~cm}]$ at the outer bottom edge of the cup. The
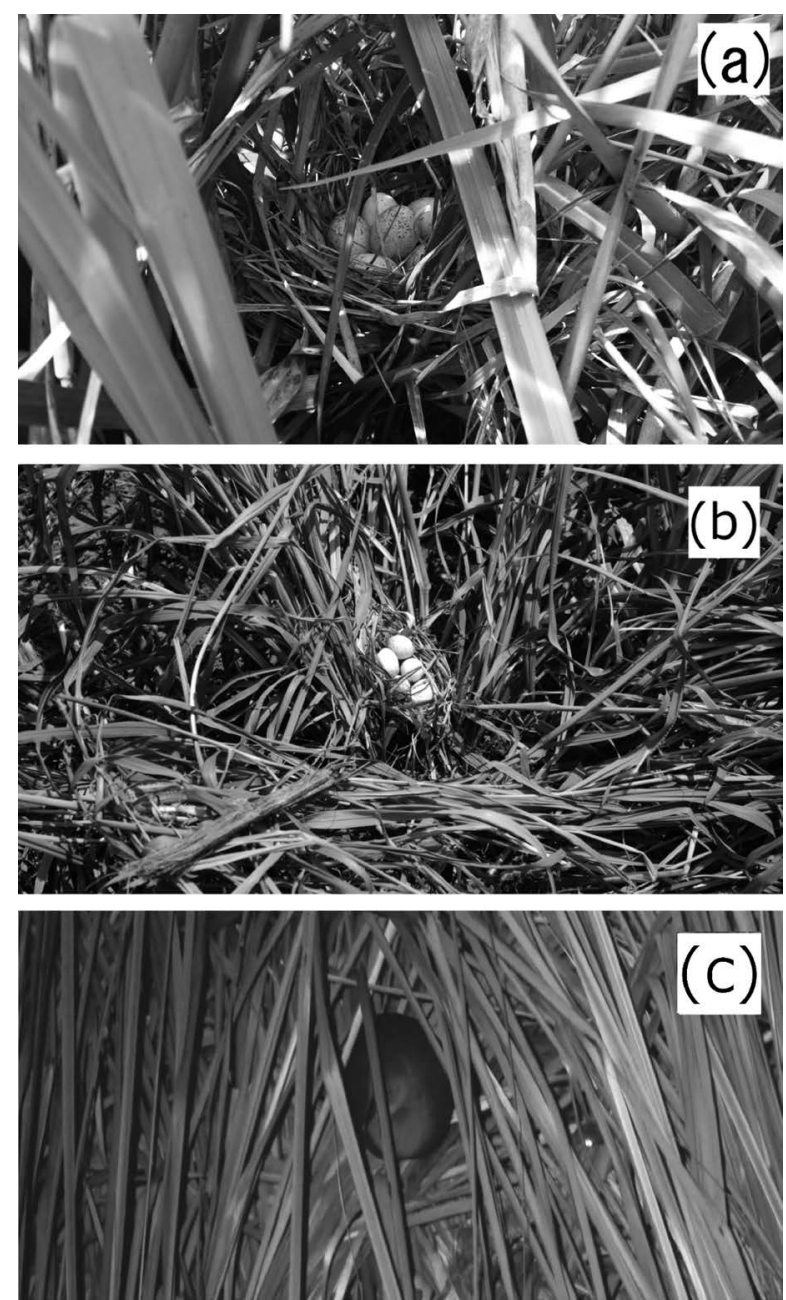

Fig. 2. (a) A Ruddy-breasted Crake nest (N3) in a swamp, with a clutch of six eggs. (b) A Ruddy-breasted Crake nest (N2) in a sugarcane field, with a clutch of five eggs. (c) An adult Ruddy-breasted Crake on roost (R2).

mean distance from the nest to the nearest dry area was $169.8 \mathrm{~cm} \pm 115.70(\mathrm{n}=5)$ [range $62-320 \mathrm{~cm}$ ].

Both R1 and R2 (Fig. 1bc) were located within Cladium chinense communities. We were unable to measure the dimensions of R2 because of its inaccessible location in a deep part of a swamp. The distance between N3 and R1 was $13 \mathrm{~m}$. The length of the major axis of the R1 was $195 \mathrm{~mm}$ and of the minor axis $154 \mathrm{~mm}$. The vertical height from the outer bottom edge to the water surface was $58 \mathrm{~cm}$ and the depth of water at the highest point of the cup was $75 \mathrm{~cm}$.

\section{DISCUSSION}

The Ruddy-breasted Crake's nest (both structure 
and location) is typical of the types made by other crakes and rails (e.g., Taylor \& van Perlo 1998; Jenkins \& Ormerod 2002). It seems that it is not restricted to nesting in areas with permanent water; Taylor and van Perlo's (1998) suggestion that in Japan nests may occur on dry cultivated vegetable fields was confirmed during our research when we discovered N2 in a dry sugar cane field more than $500 \mathrm{~m}$ (radius) from a swamp or pond. Although there has been no study on home range size in the 21-23 cm Ruddybreasted Crake, the somewhat larger Corncrake crex crex $(27-30 \mathrm{~cm})$ has a home range size within a 400 $\mathrm{m}$ radius of the nest at most (Jenkins \& Ormerod 1995; Taylor \& van Perlo 1998), indicating that (on size alone) the Ruddy-breasted Crake is likely to have a smaller home range. In addition, playback of calls led to responses from several Ruddy-breasted Crakes in dry fields on Minami-daito Island (Junpei Sawada \& Masaoki Takagi unpublised).

Swamp environments are considered most suitable for breeding Ruddy-breasted Crakes. It is inferred that nests built within swamps are protected by water from introduced terrestrial predators such as weasels and feral cats. Chicks fledged from all five of the nests that we inspected in swamps. Although dry agricultural areas, such as sugar cane fields, are safe from neither human disturbance nor terrestrial predators, nevertheless they are also available as breeding habitat for Ruddy-breasted Crakes. Further research into the ecological differences between swamps and dry fields, in terms of Ruddy-breasted Crake habitat, is recommended.

\section{ACKNOWLEDGMENTS}

We wish to express our gratitude to Tetsuya Iwasaki, Kiyoshi Asanuma, Jun-ichi Gima, Reiko Gima, Kazuaki Higashi, Mitsunori Okuyama, Hitomi Abe, Akira Sawada, and Narumi Aso for kindly supporting our field research. We appreciate the thoughtful comments on the manuscript of two anonymous referees. M.T. received funds from JSPS Kakenhi (Grant Number 16H04737).

\section{REFERENCES}

Editorial Committee of the History of Minami-daito Village (1990) Minami-daito Sonshi (The history of Minami-daito village). Revised edition. Minami-daito village office, Naha (In Japanese).

Hirano T, Gotanda K, Takamatsu T (1997) The changes of the breeding status of Ruddy-breasted Crakes Porzana fusca in Tochigi Prefecture. Accipiter 3: 1-6 (In Japanese with English summary).

Hirano T, Kimishima M, Kobori M, Kobori M \& Shiga Y (2003) Status of Ruddy Crakes in Tochigi Prefecture, central Japan in 2002. Accipiter 9: 1-9 (In Japanese with English summary).

Jenkins RKB \& Ormerod SJ (1995) Local movements and population density of Water Rails Rallus aquaticus in a small inland reedbed. Bird Study 42: 82-87.

Jenkins RKB \& Ormerod SJ (2002) Habitat preference of breeding Water Rail Rallus aquaticus. Bird Study 49: 2-10.

Minami-daito Village (2010) Sonsei Yoran (Synopsis of Minamidaito Village). The village office of Minamidaito, Okinawa.

Ministry of the Environment (2015) Red Data Book 2014. Threatened Wildlife of Japan. Vol. 2. Aves. Gyosei Corporation. Tokyo.

Okinawa Prefecture (2005) Red Data Okinawa. Nature Conservation Unit, Okinawa Prefecture, Naha (in Japanese).

Ornithological Society of Japan (2012) Check-List of Japanese Birds. Seventh Revised Edition. Ornithological Society of Japan, Sanda.

Taylor B \& Kirwan GM (2017) Ruddy-breasted Crake (Zapornia fusca). In: del Hoyo, J, Elliott A, Sargatal J, Christie DA \& de Juana E (eds) Handbook of the Birds of the World Alive. Lynx Edicions, Barcelona. (Retrieved from http://www.hbw.com/node/53664 on 22 February 2017).

Taylor B \& van Perlo B (1998) Rails. A guide to the rails, crakes, gallinules and coots of the World. Yale University Press, New Haven and London.

Watanabe Y \& Hirano T (2011) Wintering and breeding abundance of Ruddy Crakes in the western part of Kobe City. Bird Research 7: A45-A55 (in Japanese with English summary). 